\title{
Overcoming the liability of outsidership in institutional voids: trust, emerging goals and learning about opportunities
}

\begin{abstract}
Building on the complementarity of the revisited Uppsala model and effectual logic, this article examines the role of affective and cognitive trust for developing knowledge in the context of small- and medium-sized enterprise (SME) internationalization in emerging markets. Drawing on qualitative interview data from New Zealand SMEs engaging with Chinese business partners, the article first shows that an overreliance on affective trust can result in a situation of 'persistent mediation', in which learning about opportunities is impaired. Second, utilization of the affordable loss principle and a focus on control facilitates relationship-specific knowledge, which may also lead to cognitive trust. However, cognitive trust does not necessarily result in substantive business market knowledge needed to overcome the liability of outsidership. Third, business market knowledge is advanced when partners mutually set goals and develop the opportunity, which potentially also fosters cognitive and affective trust.
\end{abstract}

Keywords: affective and cognitive trust, effectuation, emerging markets, institutional voids, Uppsala model 


\section{Introduction}

Freer trade, supranational agreements and the global integration of value chains increasingly provide a more favorable cross-national institutional framework assisting small- and medium-sized enterprises (SMEs) to engage with emerging markets (Taylor and Jack, 2013). To access relevant business market knowledge and take advantage of opportunities in distant markets, SMEs need to overcome the liability of outsidership by establishing trust-based relationships with local business partners (Coviello and Munro, 1997; Johanson and Vahlne, 2003; 2009). However, doing so in distant and uncertain markets remains an ongoing challenge (Schweizer et al., 2010).

In emerging markets the liability of SMEs’ outsidership are aggravated. Enduring low institutional trust prevalent in these markets increases the importance of trust-based relationships for exploiting business opportunities, yet the processes of building fruitful relationships are not well understood by Western SMEs (Bangara et al., 2012; Smallbone and Welter, 2006). To successfully navigate uncertainties caused by incomplete or unreliable institutional systems, businesses must often invest in building trust with local business partners (Amoako and Lyon, 2014; Chen and Chen, 2004; Manikandan and Ramachandran, 2015).

At the same time, nurturing relationships in these markets brings important challenges. While strong relationships have long been considered a potential source of sustainable competitive advantage (Tsang, 1998) and supportive of business success (Yeung and Tung, 1996), the benefits of strategically pursuing relational strategies in unfamiliar markets have recently been questioned (Fan, 2002; Lin and Si, 2010). Due to various risks and a lack of market knowledge, foreign firms may achieve diminishing returns from over-relying on relationships ( $\mathrm{Li}$ et al., 2008) as new partners may inveigle their way into the network, deceit may be difficult to control and initial commitment may by be followed by later inertia in pursuing opportunities (Welter, 2012). Given such risks in building and 
activating business networks, the liability of outsidership may persist despite the best efforts of Western SMEs to nourish relevant relationships. It is therefore in situations where building and maintaining trust has the highest potential that it appears most difficult: a paradox faced by SMEs venturing into emerging markets.

Drawing on empirical evidence from New Zealand (NZ) SMEs recently engaging with partners in China, this article investigates how Western SMEs can navigate the liability of outsidership in markets characterized by institutional voids. Building on the revisited Uppsala model and effectuation logic (Galkina and Chetty, 2015; Schweizer et al., 2010), the article provides Western SMEs engaging with distributors in uncertain foreign markets with fresh insights into the interplay between commitment, trust creation and learning about opportunities. While both the Uppsala model and effectuation highlight the importance of relationships in shaping opportunities, effectual logic emphasizes the emergence of partner-contingent, non-predictive strategies to exert control over an unknowable future (Sarasvathy et al., 2014; Schweizer et al., 2010). During the engagement process, as commitment to, and knowledge about, opportunities in the foreign market increase, trust in partners is augmented. The business becomes an insider and learns about new opportunities (Galkina and Chetty, 2015). However, less is known about how, in institutional voids, different types of trust in local partners evolve, and how these influence SMEs' learning about opportunities.

The article is structured as follows. Building on the revisited Uppsala model, we discuss issues of overcoming the liability of outsidership in emerging markets, highlighting the need to build relationship knowledge to facilitate the development of business market knowledge. Trust evolves in this process. In line with Johanson and Vahlne (2009), we distinguish between the affective and cognitive dimensions of trust, and discuss their role in small firm internationalization and knowledge 
development. We also draw on effectual logic to understand the initial engagement of SMEs in unfamiliar markets without existing network partners. After developing a theoretical framework, we describe our methodology. We then present our empirical findings, which offer insights into how different trust-based relationships lead to different kinds of knowledge. By distinguishing between the affective and cognitive dimensions of trust, we highlight important complementarities between effectuation and the revisited Uppsala model. Specifically, we show that joint goal-setting activities are important in promoting knowledge sharing and learning about opportunities. Following this, we discuss the implications of our findings for theory. We finally draw some conclusions.

\section{Literature review}

\section{SME internationalization to emerging markets and the revisited Uppsala model}

Internationalizing businesses typically need to navigate environments that differ with regard to the strength and reliability of their institutional settings and the importance of trust (Fukuyama, 1995). In emerging Asian markets, institutions are often not fully developed (Welter and Smallbone, 2011), leading to less reliable and effective legal and regulatory systems (Welter and Alex, 2012). To mitigate the uncertainty caused by institutional voids and to overcome deficient contracts, firms have to rely intensively on relational contracting based on trust (Chen and Chen, 2004). It has been argued that in China, guanxi with other firms and government officials is very beneficial in developing a business (Yeung and Tung, 1996). At an individual level, guanxi refers to the interpersonal relationship between two business partners affecting the trust between them (Lee and Dawes, 2005), whereas at the network level it refers to interwoven interpersonal relationships and connections between various network firms (Zhang and Zhang, 2006). 
Western SMEs often find that entering such local networks is unattainable. Recent research has questioned the benefits to Western firms of building guanxi to do business in China (Fan, 2002; Li et al., 2008; Lin and Si, 2010). Western businesses lack the cultural "savvy” to navigate local networks and often struggle to identify suitable partners and develop social ties (Yang and Wang, 2011; Xiao and Tsui 2007). Some Western businesses may therefore rely on insiders, so called guanxi insiders or gatekeepers, to navigate local networks and establish relevant connections (Gao et al., 2014). Drawing on evidence from large businesses, Murray and Fu (2016) argue that to build guanxi in China, Western businesses may have to rely on different strategies from those of local businesses. Thus, building guanxi may not be feasible for resource-constrained Western SMEs.

The revisited Uppsala model has recognized that SMEs engaging with unfamiliar markets often face a liability of outsidership because of a lack of business market knowledge. This lack prevents the identification and exploitation of opportunities because SMEs are not part of key networks which could help them to understand and navigate the new market environment. Overcoming this challenge is critical for business growth, and depends on whether an SME can successfully build relevant relationship-specific knowledge and can leverage this into business market knowledge (Johanson and Vahlne, 2009). Building market knowledge increasingly includes learning how to navigate the embryonic relational network and how to take advantage of emerging opportunities (Galkina and Chetty, 2015). In this process, as businesses understand their partners' capabilities and potential contribution for developing the opportunity they commit and develop relationship-specific knowledge (Fletcher and Harris, 2012). Once the business's network grows, new opportunities become available, and the venture becomes increasingly intertwined with host-country business partners.

Developing these relationships involves processes of learning, building commitment and trust 
(Johanson and Vahlne, 2006; Sarasvathy et al., 2014). Trust in partners is "the willingness of a party to be vulnerable to the action of another party based on the expectation that the other will perform a particular action important to the trustor, irrespective of the ability to monitor or control the other party” (Mayer et al., 1995, p. 712). This means trust is often an important lubricant in facilitating mutual commitment and the exchange of information of SMEs with network partners. Trust is often critical for the capacity of SMEs to access or acquire business market knowledge, and if trust exists even one-off exchange relationships can offer valuable learning opportunities for building market knowledge (Geneste and Galvin, 2015). Access to knowledge through trust-based relationships enables SMEs to bypass or enhance costly experimental market learning and to grow organically within a relational setting (Gaur et al., 2011; Hohenthal et al., 2014). Simply put, it is this potential for learning about a new market that makes building commitment and trust essential for the internationalization process.

In the early stages of learning about a new market, a key managerial challenge is nurturing early contacts and fostering commitment and trust with well-established network partners (Hallen and Eisenhardt, 2012). Dedicating resources demonstrates commitment to a network and to the business opportunities that can be developed through it. While the commitment of resources in the internationalization process entails the risk of losing this specific investment (Eriksson et al. 1977), it also enables managers to gain knowledge of the market that can reduce risk and uncertainty about the opportunity (Figueira-de-Lemos et al., 2011). In this process, trust in partners evolves through the accumulation of knowledge about the relationship and the market. Changes in knowledge also alter the perception of the risk and uncertainty of the opportunity, and the willingness to commit further resources to the market (Johanson and Vahlne, 2009).

In the revisited Uppsala model trust developed in the process of gaining relationship-specific 
knowledge has different dimensions. Johanson and Valhne (2009) recognize the cognitive and affective dimensions of trust ${ }^{1}$, and argue that both play an important part in facilitating commitment and building a relationship (Vahlne and Johanson, 2013). Cognitive trust arises from a more objective assessment of the competence and reliability of the other party. It represents a calculative judgment based on accumulated knowledge built from experience (Ng and Chua, 2006). While knowledge remains incomplete, ongoing interactions provide clues about the key characteristics of the other party (McAllister, 1995), and these clues assist in evaluating and mitigating risk and in reducing exposure to opportunistic behavior. Moreover, assembling and assessing information about the reliability of the other party is often systematic, and aimed at predicting behavior, capabilities or performance (Wang et al., 2010). Affective trust, on the other hand, is based on emotional considerations (Chua et al., 2008), assessments of benevolence, and social bonds nurtured through demonstrated concern for the other party (Greenberg et al., 2007). As emotional connections deepen during relational experiences, affective trust increases, encouraging the parties to take risks that might not be objectively justifiable, and to show goodwill (Sako, 1992).

Cognitive and affective trust influence SMEs' capacity to access and acquire new knowledge. The cognitive dimension of trust has often been highlighted in relation to the process of building relevant market knowledge. Over time, the focal business gets more objective information about the capabilities of the partner and about the foreign market. Building cognitive trust with local partners is an important means for facilitating commitment and learning about opportunities in foreign markets (Johanson and Vahlne, 2003). This is because cognitive trust is often required for the acquisition of

\footnotetext{
${ }^{1}$ Another common distinction for types of trust is: contractual trust; competence (faith in the capability of the other party to deliver and meet the trustor's expectations) and goodwill trust (a belief that the other party intends to maintain a constructive and mutually beneficial relationship) (Sako, 1992; Miyamoto and Rexha, 2004). Contracts, however, are also seen as control mechanisms (Ring and van de Ven, 1998).
} 
tacit knowledge, which is critical for successful opportunity development (Levin and Cross, 2004). More recently, Johanson and Vahlne (2009) have pointed out that the affective dimension of trustbuilding "deserves a status similar to that of the cognitive dimension” (p. 1424). Affective trust also has the potential to encourage the sharing of knowledge (Swift and Hwang, 2013), and thus exporters seeking to succeed in new international markets may need to build both affective and cognitive trust (Zur et al., 2012).

Overall, there is a clear argument that interactions with partners build relationship knowledge and may lead to cognitive and affective trust. Such relational knowledge benefits learning about a market and the development of market opportunities (Johanson and Vahlne, 2003). However, how different types of trust and commitment during early market engagement with emerging markets relates to gaining market knowledge remains poorly understood.

\section{Effectual logic and engaging with unfamiliar markets}

Effectuation provides a promising approach to understanding how, in uncertain environments, initial commitments and contacts facilitate the extension of networks and the creation of new opportunities (Sarasvathy, 2001). Effectual logic focusses on the opportunity development and sees the opportunity, the goals of the business and trust in partners as important outcomes (Sarasvathy and Dew, 2008). Without existing relationship knowledge, the parties involved need to make an upfront commitment to the relationship despite uncertain returns - a leap of faith (Nooteboom, 2002; Shepherd and Zacharakis, 2001). Effectuation highlights the importance, under such conditions, of control over prediction, and of relationships in providing relevant knowledge (Chetty et al., 2015). When one activates relationships, relying on current means at hand is a key technique effectuators use to increase control over an unpredictable future (Dew et al., 2009). Thus, for the task of examining 
efforts to overcome the liability of outsidership in uncertain market environments, an effectual approach fits well (Sarasvathy et al., 2014 Johanson and Vahlne, 2009).

Effectuation logic suggests two main mechanisms through which relational knowledge promotes the creation of business opportunities. First, businesses engaging with uncertain markets will leverage existing relationship knowledge effectively. This will increase the ends they can reach given current means, and will help to identify new opportunities in foreign markets (Sarasvathy et al., 2014). Second, internationalizing into markets without established partnerships requires a dynamic view of network development. Effectual logic suggests that businesses are initially open to a variety of potential partners, and will select those willing to commit to the venture and able to provide new means, including new network partners who self-select into the opportunity by demonstrating precommitment to shared ends (Kalinic et al., 2014). Sarasvathy (2009) describes such networks as a 'crazy quilt'.

Furthermore, in order to learn fast, entrepreneurs engage in experiments and may discover new, unintended opportunities (Ries, 2011). During this process, goals, means and partnerships evolve further. Over time, the expanding network increases the resource base, particularly capabilities for leveraging means that are currently controlled, and as a result, enabling the business to reach previously unattainable ends and to pursue new opportunities in the foreign market. Increased knowledge about opportunities leads to new goals, which will be contingent on the feedback from the market and the interactions with the local partner (Sarasvathy et al., 2014).

While the commitment of the partners shapes the processes of market engagement and pursuit of opportunity in effectual logic (Wiltbank et al., 2006), there are no a priori assumptions about the level or types of trust between the partners. Hence, effectuation makes no explicit distinction between the affective and cognitive dimensions of trust. In order to participate in shaping the opportunity, 
parties may commit to the partnership without explicit judgments of trustworthiness. Their initial commitment will depend on what they can afford to lose (affordable loss) rather than on the level of trust they share (Sarasvathy and Dew, 2008). In short, action may precede trust judgments.

Effectuation helps us to understand why entrepreneurs internationalize: they perceive uncertainty as an opportunity rather than a barrier (Chetty et al., 2015). Furthermore, the affordable loss principle can explain how SMEs internationalize: they control their losses by restraining the resources they commit to international markets (Sarasvathy et al., 2014). However, how an effectual logic shapes international opportunities and how market learning and trust evolve is still open to debate (Schweizer et al., 2010; Sarasvathy et al., 2014). For example, while Kalinic et al. (2014) propose that an effectual approach reduces the amount of information required to commit to a market, and thus accelerates the internationalization process, others warn that such an approach may lead to 'over-trust', a potential liability for internationalization particularly if business fail to build their own business market knowledge (Chetty et al., 2015; Goel and Karri, 2006). However, exposure to opportunism is likely to be mitigated by the focus, in effectuation logic, on control.

Control affects the development of trust. Control may be either detrimental or beneficial in establishing trust, and the mechanisms through which control and trust interact are open to debate. While some authors argue that formal control mechanisms suppress goodwill and thus hamper the development of trust (Das and Teng, 1998; Şengün and Wasti, 2009; Strätling et al., 2012), others see trust and control as complementary (e.g. Das and Teng, 1998). Aulakh et al. (1996) found that formal control had no negative effect on trust-building. Because trusting parties develop a shared understanding and agree more easily on control procedures, trust can make formal control more effective. While the relationship between trust and control is still inconclusive, it is sensible to assume that the strategies used by internationalizing SMEs in the process of opportunity development to 
maintain control will influence the development of trust.

In this review, we have noted the difficulties that SMEs enacting opportunities in institutional voids face in addressing the liabilities of outsidership. We have also drawn attention to the revisited Uppsala model and effectual logic which both highlight the development of relationships in the enactment of opportunities in foreign markets. We have argued that in the process of SME internationalization the augmentation of trust and its effects on commitment and learning about opportunities offer a research opportunity, namely to investigate how the liabilities of outsidership can be addressed in emerging markets in which SMEs may lack relationships with existing network partners. We now proceed to our empirical study.

\section{Methodology}

To investigate how NZ SMEs have addressed the challenges of outsidership through local partnerships, and have developed opportunities with their partners, we adopted a qualitative research method. The development of trust is dynamic, and the worldviews of participants affect the underlying mechanisms (Lee, 1999). Moreover, neither the boundaries between the phenomena and contextual factors, nor the direction of causality, are self-evident (Yin, 2003; Eisenhardt, 1989). Even so, although trust is a prominent topic in the literature, it has attracted little empirical research (Welter and Smallbone, 2006). Overall, a qualitative research approach seems suitable to investigate the issue.

As our main source of data we draw upon a set of in-depth interviews with the owners or managers of SMEs engaging with Chinese markets through a distributor. Studying these relationships provides insights as to how developing certain types of trust may enable Western SMEs to overcome the liability of outsidership. Because, in China, institutional voids remain widespread, China is often considered a low-institutional trust business environment (Witt and Redding, 2013). Institutions for 
enabling private economic exchange are not yet dependable (Puffer et al., 2009; Smallbone and Welter, 2012), and limited property rights, ambiguity in contracts and arbitrariness in the enforcement of formal regulations still create uncertainty (Witt and Redding, 2013). In China, a common remedy for addressing low institutional trust is high reliance on personal relationships (Xiao and Tsui, 2007). Personal contacts increase legitimacy, enabling market entry. For businesses trying to penetrate the Chinese market, building legitimacy via trusting relationships is therefore especially relevant ( $\mathrm{Li}$ and Zhou, 2010). These considerations made Western SMEs internationalizing into China a suitable population of organizations to study

We selected participants based on considerations of theory (Eisenhardt, 1989) from a variety of sources, such as media coverage, export reports and press releases. We also utilized help from an industry expert and from an academic colleague familiar with the field (Ahlstrom et al., 2008). Potential participant SMEs needed, first, to be instrumental in the development and execution of a China strategy; second, to meet the European definition of SMEs, i.e. having fewer than 250 employees; and third, to have established a relationship with one or more distributor(s) in China that purchased from the SME at least twice a year (Yang et al., 2012).

Before we reached theoretical saturation (Eisenhardt, 1989) we conducted 26 in-depth, semistructured, face-to-face interviews with managers of such NZ SMEs from a wide range of industries, operating in different regions of the country, including urban and rural areas. We deliberately sought a diverse sample that would provide a robust foundation for theory building (Harris and Sutton, 1986). Table 1 indicates the basic characteristics of the SMEs and the interviewees.

INSERT TABLE 1 ABOUT HERE 
Each interview was conducted by a team of two researchers, following a prepared, semi-structured interview guideline that allowed us to systematically cover prominent concepts identified in the literature, such as trust, control and knowledge exchange, but that also provided an opportunity for respondents to reflect on their experience with their Chinese partners, thus allowing new topics to emerge (Eisenhardt and Graebner, 2007). The questions covered a variety of topics such as how a business partner was selected, the governance of the relationship, the role of other stakeholders, and the business's performance over time. Interviews lasted between 50 and 90 minutes. After each interview, the researchers shared notes about the interview and discussed what they had learned and how the content of the interview differed from others. Eisenhardt (1989) argues that such an approach is useful not only because it supports the data analysis, but also because the learning from early interviews provides an opportunity to capture emerging topics.

The qualitative interview data were supplemented by secondary data, including that from company websites and publicly available documents (Coviello, 2014), and by seven interviews with industry experts, such as policy makers and consultants. Using data from multiple sources triangulates findings and increases the reliability and validity of qualitative studies (Yin, 2003). The additional data helped us to obtain a better understanding of the individual SMEs and the wider context of their China engagement, and increased our confidence in the findings.

All 33 interviews were recorded, transcribed and included in a database. The coding followed an iterative approach to revisiting and categorizing the data with regard to emerging categories has been widely used in previous studies of entrepreneurship and SMEs (e.g. Gordon et al., 2012). Table 2 illustrates the iterative process of the data analysis, which involved open, axial and selective coding (Corley and Gioia, 2004; Strauss and Corbin, 1990). 


\section{INSERT TABLE 2 ABOUT HERE}

In a first step, we engaged in 'open coding' of the transcripts with the aim of capturing and identifying initial concepts that emerged during the interview. We then compared and contrasted the emerging concepts to developed higher-order categories, into which we could collapse similar concepts. For example, a higher-level category 'social activities' was created to encompass concepts such as ‘fishing' or 'karaoke’. These higher-level categories still aimed to closely resemble the language used by the participants (Corley and Gioia, 2004). During this phase, the researchers met frequently, discussed concepts and their relationship to emerging categories, and revisited the transcripts several times. By looking for new information that would provide further insights into the categories we followed the ‘constant comparative approach’ (Glaser and Strauss, 1967), aiming for saturation in coding (Creswell, 1998).

In the next phase, 'axial coding', we were particularly interested to identify important causal connections and patterns between the different categories (Creswell, 1998), leading to more nuanced categories that allowed us to identify distinct clusters of categories. For example, concepts that contained negative views on the value of contracts to manage the partnership, or highlight the effectiveness of handshake deals were collapsed into the category 'no contract'. During this phase we also engaged in a process of data reduction, eliminating irrelevant concepts that were not related to these categories (Wolcott, 1990; Eisenhardt, 1989), such as 'partner selection planned'. While many of these categories were closely related to the topics covered in the interview guideline which had been developed based on existing theory, such as trust and control in the partnership (Mantere and Ketokivi, 2013), the final categories were also shaped by the information from the participants allowing for more refined categories (Maxwell, 2005). Again, this process was not linear but iterative (Eisenhardt, 1989). 
The final phase, selective coding, involved the identification of core categories that describe different types of partner relationships underpinning our theory development. Overall, our data analysis revealed three distinct types of partner relationships with different conditions of trust development, emergence of goals and learning about opportunities (Table 3). We labelled the three types of relationship as a) ‘persistent mediation’, b) ‘experimentation’ and c) ‘opportunity cocreation'. They are discussed in more detail below.

\section{INSERT TABLE 3 ABOUT HERE}

\section{Findings}

\section{Persistent mediation and affective trust}

A group of SMEs aimed to overcome their outsidership and the disadvantages of limited market knowledge mainly by building affective trust in their partners. They believed that such network membership would enable them to obtain critical knowledge; and that while this effectual approach might reduce the amount of information required to enter the market (Kalinic et al., 2014), it can create a different liability, which we will outline later.

Affective trust was mainly developed through adopting local business practices and cultural norms to signal a willingness to engage with the market and demonstrate commitment towards a personal relationship (Table 2, column 1). SME owner-managers actively acquired knowledge of Chinese business etiquette, customs, and norms, and followed the host country protocol in business meetings and social interactions. They also engaged in social activities with their business partners, such as fishing, hiking and visits to Karaoke bars. This signaling of cultural knowledge and personal commitment was crucial for initiating a trust-based relationship, and demonstrated commitment. To take full advantage of local opportunities, some managers also suspended their suspicion of doing 
business without written contracts, and instead relied on relational contracting (Peng and Zhou, 2005).

While efforts were made to build key relationships and affective trust, this rarely resulted in learning about opportunities, but rather in 'persistent mediation' - a situation where, because of a lack of market learning, the business could access the market only through its partner. Managers were well aware that because they lacked relevant knowledge to develop the market and determine goals, they had to rely heavily on the partner to do so. While previous research has suggested that a network partner can facilitate fast market access (Kalinic et al., 2014), relying on an exclusive partner to develop the market resulted in time delays in internationalization, which made it also impossible to set goals such as growth objectives:

“Everything takes so long.... The distributor that we are looking at in Beijing ... We would have that signed up for the product going in there in March so you could say that took 13 months but there was a false start in terms of the relationship due to a couple of issues in terms of getting product there. They didn't want to see us on the second trip; we saw them on the third trip; when they were asking us then 'have you got product here because we can give you an order now.' And we said sorry we don't.... So again it is effectively 6 months.” (\#7)

While the poor performance of partners is often attributed to the self-interest and moral hazard of the partner seeking to maximize its own entrepreneurial opportunity (Chetty and Agndal, 2007), the findings identify a second mechanism leading to persistent mediation, namely choice. Choice was a response to the structural conditions imposed by institutional voids, as cultural differences often caused NZ businesses to have no interest in being integrated in the local network, and to seek a Chinese partner to manage local relationships on its own. Most managers were hesitant to engage in the corruption and bribery they believed were still part of business realities, and consequently relied 
on affective trust in partners who would navigate local networks on their behalf, allowing them to remain outsiders. By excluding themselves from negotiations with customers, they were 'out of the loop' by choice. But they did not achieve market learning, and had little control over how the value proposition was communicated to customers:

"In the cold light of day, the purchasers are not necessarily fully commercially justified; someone has got a budget to spend and a number of parties are going to be clipping the ticket along the way. So if they choose to buy 10 (of our product), I mean it is not for us to say that is a good decision or a bad decision, so long as we get paid and we are not involved in what goes on beyond the sale of the boat to the agent or dealer, we are not passing judgment on those sorts of people.” (\#23).

Reliance on building affective trust was thus perpetuated, and learning about opportunities was suppressed, further reducing the SMEs’ ability to build other types of trust, and preventing at least some from achieving their full market potential. The problems created by persistent mediation were well described by a manager who reflected on the poor performance of agents who were chosen "because we liked them and we trusted them (\#9)". He believed that his partner had withheld important information about the customers in order to retain control over the NZ SME. The partner actively prevented the business from achieving its full growth potential in the market, and the lack of access to end-customers prevented it from developing internal market knowledge:

"I know we would be more successful if we would have more transparency of the sales process. A good example is when I identified a company that I wanted to sell some ingredient to - a new one. I was talking to one of our agents and they said, oh no, I know that customer; I sell 15 ingredients to them now; let me sell to them. And 
in the end, we couldn't even get a meeting to present our concepts. The agent wouldn't tell me why not; he said they weren't interested."(\#9).

Overall, our study shows that overcoming the liability of outsidership by establishing affective trust is difficult. An overreliance on affective trust led to persistent mediation, which was found to suppress both learning about opportunities and the ability of the SME to set goals and achieve growth. Therefore, we propose the following to formally articulate this relationship:

Proposition 1: When engaging with unfamiliar markets, a focus on building affective trust only is likely to lead to low levels of knowledge about the opportunity

\section{Experimentation, learning about partners and cognitive trust}

A second group of SMEs also relied on relationships for entering China but exercised control over their partners' performance, thus provided themselves with feedback about the partners' true commitment (Sarasvathy et al., 2014). By exercising control, these SMEs established both affective and cognitive trust in partners committed to the opportunity.

First, the SME would conduct informal and formal experiments of the product's market positioning to create insights as to whether its partners were committed to its goals. Managers took advantage of short stays in the market to test the knowledge of their distributor about their products and product positioning. For example, trade fairs provided effective and relatively inexpensive learning opportunities to advise the distributor's sales personnel about the product. Other managers visited stores that had stocked their products to gain insights as to how sales staff perceived the products. Such indirect, and sometimes secret, tests provided valuable insights, including how the value proposition was communicated in the market, and whether product benefits were understood. 
Importantly, these tests were typically performed with slender resources, using a 'bootstrap finance' approach (Read et al., 2011).

"For example, in the University, there is a student group going to Guangzhou. I'm paying \$5000 and they are going to go to Guangzhou and do an assessment of some of these categories for me. So, they are going to go into Guangzhou and they are going to look at these categories here and see how my brand is doing and see how some of the private labels are doing so, for not a lot of money, I just use these students, to do an audit” (\#11).

In addition, exerting more direct control over partners was useful for determining how much the distributor knew about the product. One manager explained that testing the knowledge of the sales personnel of his distributors helped him to identify commitment to his brand with regard to knowledge and the brand message.

Second, some SMEs benchmarked the performance of multiple distributors in order to identify trustworthy and well-performing ones. This helped them to put pressure on underperformers, and to reward good performers. Such benchmarking was again achieved by conducting small, affordable experiments. For example, a manager explained how he learned about the trustworthiness of new partners by conducting affordable secret tests requiring only a container load of fruit, and thus leverage relationships with established partners:

"We are only two weeks shipping but that can still add a few compilations when you are dealing in like a certain fruit and vegetable.... They are quite happy to unpack a box and repack it with all sorts of crappy looking things and then take photos and say, half your apples are rotten or something like that.... If you are going to ship a container, ship it to five different people and make sure you include fruit or vegetables 
from the same paddock... Then you have got five different results you can compare. So if somebody says, I have got half my squash rotten. .. Then you say we send that same paddock in these four containers to these customers in your market and they didn’t complain” (\#4).

Having several distributors provides flexibility for the SME, and allows it to make plausible threats to end the relationship. SME managers would typically define goals and minimum targets for their partners, which were helpful in establishing growth objectives and thus reducing uncertainty. Written contracts often had the important function of defining and communicating goals. Thus, these contracts were established for reasons other than those that would apply in a Western business context. While in China a contract might not have been legally enforceable in the way it might be in the West, it still provided an important anchoring point for the emerging relationship, and was helpful in (a) providing a yardstick for coordinating the partnership; (b) making a partner more accountable for agreed goals; and (c) providing a tangible point for feedback and discussion on the partner's performance. Here, low contractual trust is intertwined with the development of other forms of trust, such as personal trust, the development of which requires that business transactions are negotiated and completed on mutually agreeable terms. Simple contracts can guide this dialogue, and therefore have a key function in building trust in institutional voids:

\footnotetext{
"Contractual arrangements really have to be very simple for Asia. The shorter they are, two pages, is fine. You can clarify the range; you can clarify some of the very basic fundamentals of a contract and he will sign that understanding what he has signed.” (ExpertB\#Consultant).
}

Selecting distributors and developing cognitive trust helped many SMEs to achieve fast growth. However, there was still a barrier to learning about opportunities: in some cases, the SME took control 
over the development of the business opportunity, but was not interested in learning about new opportunities:

"We are collaborating with them because we know what kind of customers are likely to buy our products.(...) It's a weekly discussion - at least a weekly discussion and then physical contact wise, it’s multiple times a year.” (\#8)

However, other managers were more critical of their understanding of the market:

“Ultimately we ended up without anybody from us managing or understanding it and we were just selling from Auckland to people who knocked on our door; what was really happening was volume (...) You are left wondering, sitting here in Auckland what happened. I used to get all these orders without knowing much more about it.” (\#11).

Overall, although the SMEs in this category did not achieve learning about opportunities through testing, short contracts or dialogue, these techniques were useful for facilitating more accountability, and supported the distributors' understanding of the attributes and benefits of the products. Testing and experimenting further enabled managers to identify unreliable partners and set incentives for growth, and reinforced their trust in established partners. They understood which partners deserved their trust, and were willing to commit further to these partners. Trust and control were thus mutually constituted. In order to work more closely with partners they trusted, some SMEs reduced, over time, the number of distributors. A closer commitment to a few partners was the first step in establishing relationships that would facilitate learning about opportunities. This leads to the second proposition:

Proposition 2: When engaging with partners in unfamiliar markets, a focus on building cognitive trust through experiments will lead to high levels of relationship specific 
knowledge, but not necessarily to high levels of business market knowledge.

\section{Opportunity co-creation, learning about opportunities and shared goals}

One group of managers, aiming to co-create opportunities, established very strong relationships with one, or very few, partner(s), relationships characterized by commitment to engage in shared efforts to develop a valuable product offering, and by mutual affective and cognitive trust. Close partnerships provided opportunities for NZ managers and Chinese partners share knowledge:

"Going with one company is working for us, we really educate that company so much
on our brand story. All the senior management have been down to NZ; they know our
founder personally; they have been to his house for dinner; they have been to all our
wineries. They know the story. ... On a daily basis, we are in contact with a brand
manager and there is a feedback cycle (\#5).

To contribute toward learning how the product could be best placed in the market, commitment from both sides was required. Often, an effective means was to have a dedicated employee working locally with the Chinese partner. SMEs that could not afford a full-time employee dedicated to the market could obtain valuable feedback through regular face-to-face meetings with the partner, or through phone/Skype calls. Managers worked together with Chinese SMEs who had complementary capabilities, and by combining insider and outsider knowledge, they co-created value. Frequent personal contact with the partner allowed stronger control of the brand story, and was helpful in facilitating the information flow between the partners. While the Chinese partner could provide better access to the market, the NZ managers often could contribute to the refinement of the market strategy, and could provide training to facilitate partners' development of the business and their ability to add 
value:

"We go back to the little guys over here who are selling to the same high end retailers and we are going they like the brand; they love what we are doing and they are going to put their heart into it. They are going to invest in the brand as well. We are probably going to need to manage their business a little bit more.” (\#3)

Such close partnerships not only created loyalty but also facilitated learning about opportunities, and helped the NZ managers to develop a feeling for local customer needs, to understand the reasons for local adaptation and to learn about local customer preferences. Importantly, these partnerships enabled mutual learning and ensured a flow of knowledge between the partners. For example, a manager explained how the local knowledge of his distributor had helped the SME to shape the opportunity for the offering:

“They want authenticity; ... imported things are regarded as king (...). So often with Chinese labelling, you think that if you have the brand story in Chinese on the bottle but that would be what we should be giving the Chinese consumer; so they can learn something about our wine from the back label. No, no, no they (our partner) say don't put a Chinese label on it; keep it in English because then it looks like it is foreign and imported and authentic.” (\#5)

Both parties were committed toward the same goal and brand story, and the SMEs expected their partner to associate itself deeply with the brand and its value proposition. A close commitment to partners was key to facilitating the development of local market knowledge. Through regular interaction, and commitment to the process of value co-creation, the business and the partner typically developed a strategy for market success. These relationships demonstrated high mutual affective and 
cognitive trust, and a win-win situation. Therefore, we propose the following:

Proposition 3: When engaging with partners in unfamiliar markets, the development of shared goals will build high levels of business market knowledge in the internationalizing SME.

\section{Discussion}

The study provides further insights into the processes that produce a complementarity between effectuation logic (Sarasvathy, 2009) and the revisited Uppsala model (Johanson and Vahlne, 2009). We investigate how SMEs develop relationships with local partners to navigate markets characterized by institutional voids. Both the revisited Uppsala model and effectual logic highlight the importance of commitment to partnerships in learning about opportunities (Schweizer et al., 2010). Specifically, effectuation logic provides a good complement for understanding the early engagement process as it can explain pre-commitment in the absence of trust judgments (Galkina \& Chetty, 2015; Kalinic et al., 2014). We contribute to theories of the role of trust in SME internationalization, knowledge creation and commitment to partnerships in institutional voids. Our study shows that there are important differences in the types of knowledge developed through the partnership depending on how trust, commitment and goals evolve over time. The theoretical implications of our study are discussed in more detail below.

In this study we distinguish between affective and cognitive trust. The importance of the affective dimension of trust has recently received more attention. Building on the importance of trust in knowledge exchange, the revisited Uppsala model suggests that affective trust should have a similar status to cognitive trust in the internationalization process (Johanson and Vahlne, 2009). By differentiating between affective and cognitive trust, our study suggests that an overreliance on affective trust leads to exposure to opportunistic behavior and can result in a situation of 'persistent 
mediation' where learning about opportunities is impaired. Moreover, withdrawal from control and the disruption of learning about partners is not necessarily an outcome of affectual 'over-trust' but can be in the strategic interest of the internationalizing SME. Navigating institutional voids may require the local partner to engage in practices that Western businesses tend to disassociate from. Western SMEs may remain outsiders by choice to safeguard their reputations. Both these processes show that the affective dimension of trust does not mitigate the liability of outsidership. Past research has highlighted the dangers, when developing an opportunity in foreign markets, of over-reliance on trust in partners (Chetty et al. 2015), and our study suggests that this danger is particularly pronounced for the affective dimension of trust.

The article further provides new insights into the relationships between effectual logic and trust creation. Some authors have argued that effectual principles, and in particular pre-commitment, may lead to 'over-trust' (Goel and Karri, 2006) or 'blind trust' (Chetty et al., 2015), increasing exposure to opportunism. Our study challenges the conclusions drawn from these studies with regard to effectual logic. While pre-commitment in combination with affective trust may lead to such exposure, our study shows how a logic of control and a focus on affordable loss is incompatible with the notion of over-trust. First, some SMEs may continuously engage with partners even though they doubt their trustworthiness, but at the same time may limit the potential losses through an effectual logic. The affordable loss principle thus can justify continuous commitment despite a lack of trust. Second, through ongoing inexpensive, affordable experiments SMEs can generate knowledge that safeguards them against cognitive over-trust. Affordable experiments are, therefore, an important mechanism for learning about the commitment and capabilities of self-selected partners, while reducing the risk of potential opportunism. Hence, similarly to Kalinic et al. (2014), the study shows that cognitive and affective trust are not necessary conditions for commitment, but may be important 
outcomes.

Cognitive trust may evolve through repeated interaction. Because evaluating partners’ potential contribution on objective criteria seems unreliable in institutional voids (Miller et al., 2009), SMEs may benchmark the performance of multiple partners through affordable experiments, which over time provides them with insights about high-performing and trustworthy partners. That is, SMEs gain cognitive trust in certain partners and will increasingly base their commitments on the level of cognitive trust in those partners rather than on their affordable loss. While SMEs may develop cognitive trust through such experiments, benchmarking and control, it still does not necessarily lead to business market knowledge, as suggested by previous research (Wu et al., 2007) but only to relationship-specific knowledge. Thus, we provide empirical evidence that addresses Welter’s (2012) call to empirically investigate the conditions under which trust may not suffice for exploiting opportunities in unfamiliar markets. Overall, the findings suggest that the liability of outsidership may persist even if affective or cognitive trust in partners can be established.

Effectual logic highlights the importance of new, emergent goals for developing and discovering new opportunities in uncertain markets (Wiltbank et al., 2006; Sarasvathy et al., 2014). Building on this, we further show that these shared goals and mutual commitment are critical for building business market knowledge. Through the efforts to further develop the opportunity, partners collaborate in experimental and mutual learning processes that require knowledge exchange and can also lead to the co-creation of new competencies. Importantly in this process, SMEs also obtain access to business market knowledge. We show an important link between mutual commitment, emergent shared goals and building business market knowledge, and we propose that the revisited Uppsala model need to include goal-setting activities as an important change variable that characterizes relationships and affects the development of business market knowledge. That is, in this 
process of mutual goal setting, businesses need to learn not only about a specific opportunity, but also about the market environment, which may enable them to pursue adjacent opportunities. Because of this, mutual goals have an important role in facilitating knowledge exchange and in overcoming the liability of outsidership.

Finally, we contribute to the understanding of legal contracts for control and the evolution of trust-based relationships under institutional voids (Welter and Alex, 2012). In emerging markets, limited enforceability reduces the incentives for SMEs to invest in arranging contracts (Amoako and Lyon, 2014). Our study shows that contracts, despite their limited legal enforceability, can play a vital role in the evolution of both the cognitive and the affective trust required for SME internationalization, and can provide a further means to exercise control over partner relationships. Contracts create a moral obligation, and provide a basis for reflection about whether network goals have been satisfactorily achieved, thereby providing an anchoring point for establishing common ground while the relationship evolves. They are a basis for discussion, and because they are enforceable from a normative perspective (Suchman, 1995), they facilitate the development of cognitive trust. Moreover, the study shows that managers deliberately force contingencies by regularly reviewing the contracts with their local partners, which can also support shared goal-setting activities. Under conditions of uncertainty, new information about the trustworthiness of partners is valuable and forcing contingencies increases control over the emerging opportunity. These functions of contracts in establishing interpersonal trust in institutional voids remain underexplored and underappreciated.

\section{Conclusion}

This study investigated processes of trust, commitment and knowledge creation in the context of 
SMEs' early market engagement with emerging markets. It contributes to our understanding of complementarities between effectual logic and the revisited Uppsala model by highlighting the role of the affordable loss principle and a focus on control in the experimental process learning about partners and a market. Moreover, by distinguishing between the affective and the cognitive dimension of trust in partners the study enhances our understanding of how SMEs learn from and with their partners about opportunities in foreign markets. Finally, the study highlights the importance of shared goals in building business market knowledge though engaging with local partners.

Our findings have implications for the owners and managers of Western SMEs aiming to engage with partners in markets characterized by institutional voids. Managers should be cautious about the relying on the affective dimension of trust. While it may provide fast access to the market through the following of cultural norms, managers can over-engage in such processes of network creation (Jack et al., 2010) at the expense of learning about opportunities. Business may be 'in the circle, but out of the loop,' as their market engagement remains mediated through the local agent. While existing research on SME internationalization highlights the building of local cultural savvy, often by using intermediaries (Gao et al., 2014), we find that an overemphasis on affective dimension of trust is a likely road to sustained outsidership.

Furthermore, the findings of this study encourage managers to continuously engage in affordable experimentation in order to learn about the trustworthiness of partners. Through such experiments, it is also possible to continue to commit to a relationship even in the absence of trust. Emerging markets offer more opportunities that SMEs can pursue, and making commitments that they can afford to lose with different partners enables them to enact multiple opportunities. Importantly, managers need to emphasize the pursuit of co-developed, shared goals, the development of which provides key learning opportunities to overcome the liability of outsidership. Finally, the 
study also draws attention to the usefulness of contracts as an important tool for manager in building trust under institutional voids, as a means at hand, despite their limited legal enforceability.

Our study has several limitations which suggest opportunities for future research. First, it draws on qualitative evidence of NZ SMEs internationalizing into China. Trust-building challenges are highly contextualized (Welter and Alex, 2012), and it is therefore uncertain to what extent are generalizable without replication. It would be of value to conduct similar studies in other emerging markets. Secondly, our study suggests that building business market knowledge can be facilitated through shared goal-setting that foster co-creation of opportunities. Further research is needed to understand better how such value co-creation can be coordinated, and sustained over time, and under what circumstances it can also enable the pursuit of adjacent opportunities in international markets. In particular, in order to better understand how shared goals change over time, and produce new capabilities and knowledge, longitudinal studies would be beneficial.

Thirdly, while we were cognizant of the importance of guanxi in China, we did not investigate guanxi creation by Western SMEs with their partners. Guanxi is an interpersonal construct and the extent to which guanxi did in fact exist in the cases we researched is impossible to establish based on data from Western managers and experts alone: recent evidence, after all, questions whether Western business can ever establish guanxi in China (Li et al., 2008; Murray and Fu, 2016). Further research could more directly investigate strategies to pursue, and mechanisms to establish, guanxi, by mapping networks of relationships or by collecting dyadic data on the relationships between Western managers and their Chinese partners.

Overall, more research is needed on how businesses can navigate institutional voids amidst actual or potential partners with uncertain qualities and intentions. Creating opportunities in such capricious business climates requires a deep understanding of how business market knowledge can be 
gained by nurturing relationships. This study has offered theoretical and practical implications and developed propositions for the early stages of engagement with an uncertain and unfamiliar market. However, future studies could investigate at what point trust, once build, starts to erode or perishes. 


\section{References}

Ahlstrom D, Bruton GD and Yeh KS (2008) Private firms in China: Building legitimacy in an emerging economy. Journal of World Business 43(4): 385-399.

Amoako IO and Lyon F (2014) 'We don't deal with courts': Cooperation and alternative institutions shaping exporting relationships of small and medium-sized enterprises in Ghana. International Small Business Journal 32(2): 117-139.

Ardichvili A, Cardozo R and Ray S (2003) A theory of entrepreneurial opportunity identification and development. Journal of Business Venturing 18(1): 105-123.

Aulakh PS, Kotabe M and Sahay A (1996) Trust and performance in cross-border marketing partnerships: A behavioral approach. Journal of International Business Studies 27(5): 10051032.

Bangara A, Freeman S and Schroder W (2012) Legitimacy and accelerated internationalization: An Indian perspective. Journal of World Business 47(4): 623-634.

Chen XP and Chen CC (2004) On the intricacies of the Chinese guanxi: A process model of guanxi development. Asia Pacific Journal of Management 21(3): 305-324.

Chetty S and Agndal H (2007) Social capital and its influence on changes in internationalization mode among small and medium-sized enterprises. Journal of International Marketing 15(1): $1-29$.

Chetty S, Ojala A and Leppäaho T (2015) Effectuation and foreign market entry of entrepreneurial firms. European Journal of Marketing 49(9/10): 1436-1459.

Chua RY, Ingram P and Morris MW (2008). From the head and the heart: Locating cognition-and affect-based trust in managers' professional networks. Academy of Management Journal 51(3): 436-452.

Corbin JM and Strauss A (1990) Grounded theory research: Procedures, canons, and evaluative criteria. Qualitative Sociology 13(1): 3-21.

Coviello N and Munro H (1997) Network relationships and the internationalization process of small software firms. International Business Review 6(4): 361-386.

Coviello N (2014) How to publish qualitative entrepreneurship research in top journals. In Fayolle A and Wright M (eds) How to Get Published in the Best Entrepreneurship Journals: A Guide to Steer Your Academic Career, Cheltenham: Edward Elgar, pp.167-182.

Creswell, JW (1998). Qualitative inquiry and research design: Choosing among five traditions. London: Sage.

Das TK and Teng BS (1998) Between trust and control: Developing confidence in partner cooperation in alliances. Academy of Management Review 23(3): 491-512.

Dew N, Read S, Sarasvathy SD and Wiltbank R (2011) On the entrepreneurial genesis of new markets: effectual transformations versus causal search and selection. Journal of Evolutionary Economics 21(2): 231-253.

Dew N, Read S, Sarasvathy SD and Wiltbank R (2009) Effectual versus predictive logics in entrepreneurial decision-making: Differences between experts and novices. Journal of Business Venturing 24(4): 287-309.

Eisenhardt KM (1989) Building Theories from Case Study Research. Academy of Management Journal 32(3): 543-576.

Eisenhardt KM and Graebner ME (2007) Theory building from cases: Opportunities and challenges. Academy of Management Journal 50(1): 25-32.

Eriksson, K., Johanson, J., Majkgard, A., \& Sharma, D. D. (1997). Experiential knowledge and cost 
in the internationalization process. Journal of international business studies, 337-360.

Fan, Y (2002) Questioning guanxi: definition, classification and implications. International Business Review 11(5): 543-561.

Figueira-de-Lemos, F., Johanson, J., \& Vahlne, J. E. (2011). Risk management in the internationalization process of the firm: A note on the Uppsala model. Journal of World Business, 46(2), 143-153.

Fletcher M and Harris S (2012) Knowledge acquisition for the internationalization of the smaller firm: Content and sources. International Business Review 21(4): 631-647.

Fukuyama F (1995) Trust: The social virtues and the creation of prosperity. New York: Free Press.

Galkina T and Chetty S (2015) Effectuation and networking of internationalizing SMEs. Management International Review 55(5): 647-676.

Gao H, Knight JG, Yang Z, et al (2014) Toward a gatekeeping perspective of insider-outsider relationship development in China. Journal of World Business 49(3): 312-320.

Gaur AS, Mukherjee D, Gaur SS and Schmid F (2011) Environmental and Firm Level Influences on Inter-Organizational Trust and SME Performance. Journal of Management Studies 48(8): 1752-1781.

Geneste LA and Galvin P (2015) Trust and knowledge acquisition by small and medium-sized firms in weak client-firm exchange relationships. International Small Business Journal 30(3): 277298.

Glaser BS and Strauss A (1967) The discovery of grounded theory. Strategies for qualitative research. London: Weidenfeld and Nicolson.

Goel S and Karri R (2006) Entrepreneurs, effectual logic, and over-trust. Entrepreneurship Theory and Practice 30(4): 477-493.

Gordon I, Hamilton E and Jack S (2012) A study of a university-led entrepreneurship education programme for small business owner/managers. Entrepreneurship \& Regional Development 24(9-10): 767-805.

Greenberg PS, Greenberg RH and Antonucci YL (2007) Creating and sustaining trust in virtual teams. Business Horizons 50(4): 325-333.

Hallen BL and Eisenhardt KM (2012). Catalyzing strategies and efficient tie formation: How entrepreneurial firms obtain investment ties. Academy of Management Journal 55(1): 35-70.

Harris SG and Sutton RI (1986) Functions of parting ceremonies in dying organizations. Academy of Management Journal 29(1): 5-30.

Hilmersson M and Jansson H (2012) International network extension processes to institutionally different markets: entry nodes and processes of exporting SMEs. International Business Review 21(4): 682-693.

Hohenthal J, Johanson J and Johanson M (2014) Network knowledge and business-relationship value in the foreign market. International Business Review 23(1): 4-19.

Jack S, Moult S, Anderson AR, et al (2010) An entrepreneurial network evolving: Patterns of change. International Small Business Journal 28(4): 315-337.

Johanson J and Vahlne JE (2009) The Uppsala internationalization process model revisited: From liability of foreignness to liability of outsidership. Journal of International Business Studies 40(9): 1411-1431.

Johanson J and Vahlne JE (2006) Commitment and opportunity development in the internationalization process: A note on the Uppsala internationalization process model.

Management International Review 46(2): 165-178.

Johanson J and Vahlne JE (2003) Business relationship learning and commitment in the 
internationalization process. Journal of International Entrepreneurship 1(1): 83-101.

Kalinic I, Sarasvathy SD and Forza C (2014) 'Expect the unexpected’: Implications of effectual logic on the internationalization process. International Business Review 23(3): 635-647.

Kautonen T, Zolin R, Kuckertz A and Viljamaa A (2010) Ties that blind? How strong ties affect small business owner-managers’ perceived trustworthiness of their advisors. Entrepreneurship and Regional Development 22(2): 189-209.

Laaksonen T, Pajunen K, and Kulmala HI (2008) Co-evolution of trust and dependence in customersupplier relationships. Industrial Marketing Management 37(8): 910-920.

Lee DY and Dawes PL (2005) Guanxi, trust, and long-term orientation in Chinese business markets. Journal of International Marketing 13(2): 28-56.

Lee TW (1999) Using Qualitative Methods in Organizational Research. Thousand Oaks, CA: Sage.

Levin DZ and Cross R (2004) The strength of weak ties you can trust: The mediating role of trust in effective knowledge transfer. Management Science 50(11): 1477-1490.

Li JJ, Poppo L and Zhou KZ (2008) Do managerial ties in China always produce value? Competition, uncertainty, and domestic vs. foreign firms. Strategic Management Journal 29(4): 383-400.

Li, JJ and Zhou KZ (2010) How foreign firms achieve competitive advantage in the Chinese emerging economy: Managerial ties and market orientation. Journal of Business Research 63(8): 856-862.

Lin J and Si SX (2010) Can guanxi be a problem? Contexts, ties, and some unfavorable consequences of social capital in China. Asia Pacific Journal of Management 27(3): 561-581.

Lincoln YS and Guba EG (1985) Naturalistic inquiry (Vol. 75). London: Sage.

Mair J, Martí I and Ventresca MJ (2012) Building inclusive markets in rural Bangladesh: How intermediaries work institutional voids. Academy of Management Journal 55(4): 819-850.

Manikandan KS and Ramachandran J (2015) Beyond institutional voids: Business groups, incomplete markets, and organizational form. Strategic Management Journal 36(4): 598-617.

Mantere S and Ketokivi M (2013) Reasoning in organization science. Academy of Management Review 38(1): 70-89.

Maxwell JA (2005) Qualitative research design: An interactive approach (2nd ed.). Thousand Oaks, CA: Sage Publications.

Mayer RC, Davis JH and Schoorman FD (1995) An integrative model of organizational Trust. Academy of Management Review 20(3), 709-34.

McAllister DJ (1995) Affect-and cognition-based trust as foundations for interpersonal cooperation in organizations. Academy of Management Journal 38(1): 24-59.

Miles MB and Huberman AM (1994) Qualitative data analysis: An expanded sourcebook (2 ${ }^{\text {nd }}$ ed.). Thousand Oaks, CA: Sage.

Miller D, Lee J, Chang S and Le Breton-Miller I (2009) Filling the institutional void: The social behavior and performance of family vs non-family technology firms in emerging markets. Journal of International Business Studies 40(5): 802-817.

Miyamoto T and Rexha N (2004) Determinants of three facets of customer trust: A marketing model of Japanese buyer-supplier relationship. Journal of Business Research 57(3): 312-319.

Murray JY and Fu FQ (2016) Strategic guanxi orientation: How to manage distribution channels in China?. Journal of International Management 22(1): 1-16.

Neergaard H and Ulhøi JP (2006) Government agency and trust in the formation and transformation of interorganizational entrepreneurial networks. Entrepreneurship Theory and Practice 30(4): 519-539.

Ng NY and Chua RYJ (2006) Do I contribute more when I trust more? Differential effects of 
cognition- and affect-based trust. Management and Organization Review 2: 43-66.

Nooteboom B (2002) Trust: Forms, Foundations, Functions, Failures and Figures. Cheltenham: E. Elgar Publishing.

Peng MW and Zhou JQ (2005) How Network Strategies and Institutional Transitions Evolve in Asia. Asia Pacific Journal of Management 22(4): 321-336.

Puffer SM, McCarthy DJ and Boisot M (2009) Entrepreneurship in Russia and China: The impact of Formal Institutional Voids. Entrepreneurship Theory and Practice 34(3): 441-467.

Read S, Sarasvathy SD, Dew N, Wiltbank R and Ohlsson AV (2011). Effectual entrepreneurship. New York: Routledge.

Ries E (2011) The lean startup: How today's entrepreneurs use continuous innovation to create radically successful businesses. Crown Books.

Ring PS and Van de Ven AH (1992) Structuring cooperative relationships between organizations. Strategic Management Journal 13(7): 483-498.

Sako M (1992) Prices, quality and trust: Inter-firm relations in Britain and Japan. New York: Cambridge University Press.

Sarasvathy SD (2009) Effectuation: Elements of entrepreneurial expertise. Edward Elgar Publishing. Sarasvathy SD (2001) Causation and Effectuation: Toward a Theoretical Shift from Economic Inevitability to Entrepreneurial Contingency. Academy of Management Review 26(2): 243263.

Sarasvathy SD and Dew N (2008) Effectuation and Over-Trust: Debating Goel and Karri. Entrepreneurship Theory and Practice 32(4): 727-737.

Sarasvathy SD, Kumar K, York JG, et al (2014) An effectual approach to international entrepreneurship: Overlaps, challenges, and provocative possibilities. Entrepreneurship Theory and Practice 38(1): 71-93.

Schweizer R, Vahlne JE and Johanson J (2010) Internationalization as an entrepreneurial process. Journal of International Entrepreneurship 8(4): 343-370.

Şengün AE and Wasti SN (2009) Revisiting Trust and Control Effects on Perceived Relationship Performance. International Small Business Journal 27(1): 39-69.

Shepherd DA and Zacharakis A (2001) The venture capitalist-entrepreneur relationship: Control, trust and confidence in co-operative behaviour. Venture Capital 3(2): 129-149.

Smallbone D and Welter F (2012) Entrepreneurship and institutional change in transition economies: The Commonwealth of Independent States, Central and Eastern Europe and China compared. Entrepreneurship \& Regional Development: An International Journal 24(3/4): 215-233.

Smallbone D and Welter F (2006) Conceptualising entrepreneurship in a transition context. International Journal of Entrepreneurship and Small Business 3(2): 190-206.

Strätling R, Wijbenga FH and Dietz G (2012) The impact of contracts on trust in entrepreneurventure capitalist relationships. International Small Business Journal 30(8): 811-831.

Suchman, MC (1995) Managing legitimacy: Strategic and institutional approaches. Academy of Management Review 20(3): 571-610.

Swift PE and Hwang A (2013) The impact of affective and cognitive trust on knowledge sharing and organizational learning. The Learning Organization 20(1): 20-37.

Taylor M and Jack R (2013) Understanding the pace, scale and pattern of firm internationalization: An extension of the 'born global' concept. International Small Business Journal 31(6): 701721.

Tsang EW (1998) Can guanxi be a source of sustained competitive advantage for doing business in China?. The Academy of Management Executive 12(2): 64-73. 
Vahlne JE and Johanson J (2013) The Uppsala model on evolution of the multinational business enterprise-from internalization to coordination of networks. International Marketing Review 30(3): 189-210.

Wang S, Tomlinson EC and Noe RA (2010) The role of mentor trust and protégé internal locus of control in formal mentoring relationships. Journal of Applied Psychology 95(2): 358-367.

Welter F and Alex N (2012) Researching trust in different cultures. In: Lyon F, Möllering G and Saunders M (eds) Handbook of Research Methods on Trust. Cheltenham: Edward Elgar, pp.50-60.

Welter F and Smallbone D (2006) Exploring the role of trust in entrepreneurial activity, Entrepreneurship: Theory and Practice 30(4): 465-475.

Welter F and Smallbone D (2011) Institutional perspectives on entrepreneurial behavior in challenging environments. Journal of Small Business Management 49(1): 107-125.

Welter F (2012) All you need is trust? A critical review of the trust and entrepreneurship literature. International Small Business Journal 30(3): 193-212.

Wiltbank R, Dew N, Read S and Sarasvathy SD (2006) What to do next? The case for non-predictive strategy. Strategic Management Journal 27(10): 981-998.

Witt MA and Redding G (2013) China: Authoritarian Capitalism. In: Witt MA and Redding G, editors. The Oxford Handbook of Asian Business Systems (pp. 11-32). Oxford, UK: Oxford University Press.

Wolcott HF (1990) Writing up qualitative research (Vol. 20). City: Newbury Park, CA: Sage.

Wu F, Sinkovics RR, Cavusgil ST, et al. (2007) Overcoming export manufacturers’ dilemma in international expansion. Journal of International Business Studies 38(2): 283-302.

Xiao Z and Tsui AS (2007) When Brokers May Not Work: The Cultural Contingency of Social Capital in Chinese High-tech Firms. Administrative Science Quarterly 52(1): 1-31.

Yang Z, Su C and Fam KS (2012) Dealing with institutional distances in international marketing channels: Governance strategies that engender legitimacy and efficiency. Journal of Marketing 76(3): 41-55.

Yang Z and Wang CL (2011) Guanxi as a governance mechanism in business markets: Its characteristics, relevant theories, and future research directions. Industrial Marketing Management 40: 492-495.

Yeung IY and Tung RL (1996) Achieving business success in Confucian societies: The importance of guanxi (connections). Organizational Dynamics 25(2): 54-65.

Yin RK (2003) Case Study research: Design and Methods ( $3^{\text {rd }}$ ed.) Thousand Oaks, CA: Sage.

Zhang Y and Zhang Z (2006) Guanxi and organizational dynamics in China: a link between individual and organizational levels. Journal of Business Ethics 67(4): 375-392.

Zur A, Leckie C and Webster CM (2012) Cognitive and affective trust between Australian exporters and their overseas buyers. Australasian Marketing Journal 20(1): 73-79. 